\title{
FAKTOR-FAKTOR YANG MEMENGARUHI PENYERAPAN TENAGA KERJA IBS PROVINSI JAWA TIMUR TAHUN 2019
}

\author{
(FACTORS AFFECTING THE ABSORPTION OF LARGE MEDIUM INDUSTRY LABOR IN EAST JAVA \\ PROVINCE IN 2019)
}

\author{
Adinda Haya Shafira ${ }^{1}$, Krismanti Tri Wahyuni ${ }^{2}$ \\ Politeknik Statistika STIS ${ }^{1}$ \\ Politeknik Statistika STIS 2 \\ Jalan Otto Iskandardinata No. 64C, Jatinegara, Jakarta Timur, Daerah Khusus Ibukota Jakarta 13330 \\ E-mail: 111709492@stis.ac.id
}

\begin{abstract}
ABSTRAK
Keberhasilan pembangunan ekonomi suatu negara dientukan oleh sumber daya manusianya, tetapi jumlah penduduk yang besar tidak selalu menjamin keberhasilan pembangunan bahkan dapat menjadi beban bagi keberlangsungan pembangunan apabila tidak dapat dimanfaatkan secara maksimal. Sektor industri selain berperan sebagai sektor utama dalam pembangunan ekonomi, juga berpotensi untuk menyerap tenaga kerja dalam jumlah yang besar. Namun faktanya Provinsi Jawa Timur belum dapat memenuhi hal tersebut, dimana penyerapan tenaga kerja sektor industri masih tertinggal dibandingkan dengan sektor pertanian dan perdagangan walaupun sektor industri merupakan leading sector dan kontributor PDRB terbesar Provinsi Jawa Timur. Tujuan dari penelitian ini adalah untuk mengetahui, menggambarkan, dan menganalisis faktor-faktor yang memengaruhi penyerapan tenaga kerja industri besar dan sedang di Provinsi Jawa Timur tahun 2019. Metode yang digunakan adalah analisis regresi linear berganda (RLB). Hasil analisis menunjukkan bahwa minimal terdapat satu variabel independen yang berpengaruh signifikan terhadap penyerapan tenaga kerja sektor industri besar sedang Provinsi Jawa Timur tahun 2019. Secara parsial, variabel jumlah perusahaan dan PDRB berpengaruh signifikan dan positif terhadap penyerapan tenaga kerja sektor industri besar sedang Provinsi Jawa Timur tahun 2019. Sedangkan variabel UMK tidak berpengaruh signifikan terhadap penyerapan tenaga kerja sektor industri besar sedang Provinsi Jawa Timur tahun 2019, karena peningkatan upah menjadi beban bagi perusahaan.
\end{abstract}

Kata kunci: tenaga kerja, industri besar sedang, PDRB, regresi linear berganda

\section{ABSTRACT}

The success of a country's economic development is determined by its human resources, but the large population does not always guarantee the success of development and can even become a burden for the sustainability of development if it cannot be maximally utilized. . Apart from having a role as the main sector in economic development, the industrial sector also has the potential to absorb a large number of workers. However, the fact is that the province of East Java has not been able to fulfill this, where the absorption of labor in the industrial sector is still behind compared to the agricultural and trade sectors even though the industrial sector is the leading sector and the largest contributor to GRDP of East Java Province. The purpose of this study is to identify, describe, and analyze the factors that affect the employment of large and medium industries in East Java Province in 2019. The method used is multiple linear regression analysis (RLB). The results of the analysis show that at least one independent variable has a significant effect on the absorption of labor in the large and medium industrial sector in East Java Province in 2019. Partially, the variables of the number of companies and GRDP have a significant and positive effect on the absorption of labor in the large and medium industrial sector in East Java Province in 2019. 2019. Meanwhile, the UMK variable does not have a significant effect on the absorption of labor in the large and medium-sized industrial sector in East Java Province in 2019, because the increase in wages is a burden for the company.

Keywords: labor, medium large industry, GRDP, multiple linear regression

\section{PENDAHULUAN}

Salah satu indikator untuk menilai keberhasilan pembangunan ekonomi suatu negara dilihat dari kesempatan kerja yang diciptakan dari hasil pembangunan ekonomi yang sedang dilaksanakan. Pembangunan ekonomi melibatkan sumber daya manusia sebagai salah satu pelaku dalam melaksanakan pembangunan. Jumlah penduduk yang besar tidak selalu menjamin keberhasilan pembangunan bahkan 
dikatakan dapat menjadi beban bagi keberlangsungan pembangunan tersebut. Jumlah penduduk yang terlalu besar dan tidak sebanding dengan ketersediaan lapangan kerja akan menyebabkan sebagian dari penduduk yang berada pada usia kerja tidak memperoleh pekerjaan. Salah satu kebijakan yang dilakukan oleh pemerintah untuk mempercepat terlaksananya pembangunan ekonomi adalah melalui industrialisasi. Proses industrialisasi merupakan suatu proses interaksi antara pengembangan teknologi, inovasi, spesialisasi dalam produksi dan perdagangan antar negara yang pada akhirnya sejalan dengan peningkatan pendapatan perkapita yang mendorong perubahan struktur ekonomi. Oleh karena itu, proses industrialisasi didalam perekonomian sering juga diartikan sebagai proses perubahan struktur ekonomi (Tambunan, 2001).

Provinsi Jawa Timur sebagai provinsi di Pulau Jawa yang mempunyai potensi besar terhadap industri pengolahan. Berdasarkan data BPS tahun 2017, sebesar 24,5 persen perusahaan industri pengolahan di Pulau Jawa berada di Provinsi Jawa Timur. Jika melihat kontribusi PDB sektor industri tahun 2018, provinsi Jawa Timur memberikan kontribusi sebesar 21,3 persen. Hal ini membuktikan Provinsi Jawa Timur merupakan salah satu provinsi dengan potensi besar terhadap pembangunan ekonomi melalui sektor industri pengolahan di Indonesia.

Dengan jumlah penduduk terbanyak kedua di Indonesia menurut proyeksi penduduk yang dilakukan oleh BPS pada tahun 2015 dengan jumlah penduduk pada tahun 2017 sebesar 39,3 juta jiwa. Hal ini dapat menjadi tantangan sekaligus peluang dalam menghadapi dan mengatasi masalah pengangguran dan ketenagakerjaan. Penyerapan tenaga kerja pada sektor industri pengolahan di Provinsi Jawa Timur berada pada urutan ketiga setelah Provinsi Jawa Barat dan Provinsi Jawa Tengah.

Struktur perekonomian Jawa Timur masih didominasi oleh tiga sektor yaitu, sektor industri pengolahan, kemudian sektor perdagangan, hotel dan restoran, serta sektor pertanian. Sektor industri pengolahan sebagai sektor utama (leading sector) yang memiliki kontribusi terbesar dalam pembentukan PDRB Provinsi Jawa Timur. Pada tahun 2019, sektor industri pengolahan memberikan kontribusi sebesar 30,23 persen. Sektor industri memiliki kontribusi yang besar terhadap PDRB Jawa Timur diharapkan mampu menyerap banyak tenaga kerja dan menurunkan tingkat pengangguran. Namun, tingginya kontribusi sektor industri terhadap PDRB Jawa Timur belum diimbangi dengan penyerapan tenaga kerja di sektor tersebut. Pada tahun 2017 sektor industri pengolahan memberikan kontribusi sebesar 15 persen terhadap total tenaga kerja di Jawa Timur. Nilai ini masih jauh jika dibandingkan dengan sektor pertanian yang mampu menyerap tenaga kerja sebesar 33 persen dan sektor perdagangan sebesar 23 persen. Sektor industri dapat menjadi sektor utama yang mampu menyerap lebih banyak tenaga kerja namun, keadaan ketenagakerjaan di Provinsi Jawa Timur masih didominasi oleh sektor pertanian. Hal ini tidak sejalan dengan rencana pemerintah Provinsi Jawa Timur yang mempunyai visi dalam pembangunan industri yaitu menjadikan Jawa Timur sebagai pusat industri dan perdagangan terkemuka, berdaya saing global, dan berperan sebagai motor penggerak utama perekonomian dalam rangka peningkatan kesejahteraan masyarakat.

Tujuan dari penelitian ini adalah menjelaskan keadaan ketenagakerjaan sektor industri besar sedang di Provinsi Jawa Timur pada tahun 2019, menjelaskan keadaan perusahaan industri besar sedang, PDRB ADHB sektor industri pengolahan, dan Upah Minimum Kabupaten/Kota di Provinsi Jawa Timur pada tahun 2019, dan menganalisis faktor-faktor apa saja yang dapat memengaruhi penyerapan tenaga kerja sektor industri di Provinsi Jawa Timur pada tahun 2019.

\section{METODOLOGI}

\section{LANDASAN TEORI}

Menurut Undang-Undang No. 13 Tahun 2003 tentang Ketenagakerjaan yang tercantum dalam Bab 1 Pasal 1 Ayat 2 menyebutkan, tenaga kerja adalah setiap orang yang mampu melakukan pekerjaan guna menghasilkan barang dan jasa baik untuk memenuhi kebutuhan sendiri maupun untuk masyarakat. Dalam Undang-Undang No. 25 Tahun 1997 telah ditetapkan batas usia kerja yaitu 15 tahun keatas.

Permintaan tenaga kerja adalah hubungan antara tingkat upah dan jumlah tenaga kerja yang dikehendaki oleh pengusaha untuk dipekerjakan dalam jangka waktu tertentu (Simanjuntak, 2001). Permintaan tenaga kerja berkaitan dengan jumlah tenaga kerja yang dibutuhkan atau diserap oleh perusahaan atau instansi tertentu. Menurut Sumarsono (2009), faktor yang mempengaruhi permintaan tenaga kerja adalah perubahan tingkat upah, perubahan permintaan pasar terhadap hasil produksi, serta harga barang modal.

Pengertian industri pengolahan yang dijelaskan oleh Badan Pusat Statistik (2017) adalah suatu kegiatan ekonomi yang melakukan kegiatan mengubah suatu barang dasar secara mekanis, kimia, atau dengan tangan sendiri sehingga menjadi barang jadi atau setengah jadi, dan atau barang yang kurang nilainya menjadi barang yang lebih tinggi nilainya, dan sifatnya lebih dekat kepada konsumen akhir. Sedangkan perusahaan industri adalah unit atau kesatuan usaha yang melakukan kegiatan ekonomi, bertujuan menghasilkan barang atau jasa, terletak pada suatu bangunan atau lokasi tertentu, dan mempunyai catatan 
administrasi tersendiri mengenai produksi atau struktur biaya serta ada seorang atau lebih yang bertanggung jawab atas usaha tersebut (BPS, 2017).

Produk domestik regional atau daerah adalah semua barang dan jasa yang dihasilkan dari kegiatankegiatan ekonomi yang berlangsung di wilayah domestik, tanpa melihat asal dan kepemilikan faktor produksi dari penduduk daerah tersebut ataupun tidak (BPS, 2019). Penghitungan produk domestik lebih dikenal dengan istilah Produk Domestik Regional Bruto (PDRB), disebut domestik karena menyangkut batas wilayah dan dinamakan bruto karena telah memasukkan komponen penyusutan dalam perhitungannya.

Penetapan upah minimum yang diatur dalam Peraturan Menteri Ketenagakerjaan dan Transmigrasi Nomor 7 Pasal 1 Tahun 2013 adalah standar yang ditetapkan oleh pemerintah sehubungan dengan upah yang diterima oleh pegawai/karyawan di sebuah badan usaha yang terdiri dari upah pokok bulanan termasuk tunjangan tetap (biasanya meliputi, namun tidak terbatas pada, uang makan, uang transport, tunjangan kesehatan, asuransi dan lainnya).

\section{METODE PENGUMPULAN DATA}

Data yang digunakan adalah data sekunder dari 38 kabupaten/kota di Provinsi Jawa Timur yaitu, Pacitan, Ponorogo, Trenggalek, Tulungagung, Blitar, Kediri, Malang, Lumajang, Jember, Banyuwangi, Bondowoso, Situbondo, Probolinggo, Pasuruan, Sidoarjo, Mojokerto, Jombang, Nganjuk, Madiun, Magetan, Ngawi, Bojonegoro, Tuban, Lamongan, Gresik, Bangkalan, Sampang, Pamekasan, Sumenep, Kota Kediri, Kota Blitar, Kota Malang, Kota Probolinggo, Kota Pasuruan, Kota Mojokerto, Kota Madiun, Kota Surabaya, dan Kota Batu, yang bersumber dari Badan Pusat Statistik dan Dinas Tenaga Kerja dan Transmigrasi Provinsi Jawa Timur dengan periode tahun 2019. Data yang digunakan pada penelitian ini antara lain jumlah tenaga kerja industri besar sedang sebagai variabel dependen serta jumlah perusahaan industri besar sedang, PDRB sektor industri pengolahan, dan UMK sebagai variabel independen. Dimana data mengenai jumlah tenaga kerja dan jumlah perusahaan industri besar sedang didapatkan melalui publikasi Provinsi Jawa Timur dalam Angka 2020, nilai PDRB sektor industri pengolahan didapatkan melalui tabel dinamis statistik dasar pada website BPS Provinsi Jawa Timur, serta nilai UMK yang diperoleh dari Keputusan Gubernur Provinsi Jawa Timur melalui Dinas Tenaga Kerja dan Transmigrasi Provinsi Jawa Timur.

\section{METODE ANALISIS}

Metode analisis yang digunakan dalam penelitian ini adalah analisis deskriptif dan analisis inferensia. Analisis deskriptif merupakan analisis yang menggambarkan atau memberikan visualisasi data dalam bentuk tabel maupun grafik. Sedangkan analisis inferensia menggunakan regresi linier berganda (RLB). Analisis inferensia digunakna ntuk mengetahui pengaruh faktor-faktor yang signifikan mempengaruhi permintaan tenaga kerja sektor industri besar sedang di Provinsi Jawa Timur tahun 2019. Variabel independen yang digunakan dalam penelitian ini adalah jumlah perusahaan industri besar sedang $\left(X_{1}\right)$, nilai PDRB sektor industri pengolahan $\left(\mathrm{X}_{2}\right)$, dan UMK Provinsi Jawa Timur tahun $2019\left(\mathrm{X}_{3}\right)$. Sehingga model regresi yang terbentuk adalah sebagai berikut:

$$
Y_{i}=\beta_{0}+\beta_{1} X_{i 1}+\beta_{2} X_{i 2}+\beta_{3} X_{i 3}+\varepsilon_{i}
$$

dimana:

$Y_{i} \quad$ : jumlah tenaga kerja sektor industri besar sedang menurut kabupaten/kota ke-i

$\beta_{0} \quad:$ intercept

$\beta_{1}, \beta_{2}, \beta_{3}$ : parameter koefisien regresi dari variabel independen

$X_{1}, X_{2}, X_{3}$ : variabel independen

$\varepsilon_{i} \quad$ : error observasi ke-i

i $\quad: 1,2,3, \ldots, 38$ (banyaknya kabupaten/kota di Provinsi Jawa Timur)

Sebelum dilanjutkan dengan menginterpretasikan nilai-nilai pada model regresi, akan dianalisis terlebih dahulu hasil uji asumsi klasik dan uji kelayakan modelnya. Pemeriksaan asumsi klasik diantaranya adalah uji heteroskedastisitas menggunakan uji Glejser, uji normalitas menggunakan uji Jarque-Bera, uji multikolinieritas menggunakan VIF (Variance Influence Factor), dan uji autokorelasi menggunakan uji Durbin Watson. Pengujian kelayakan model diantaranya uji simultan (uji $\mathrm{F}$ ), koefisien determinasi menggunakan Adjusted $R^{2}$, dan uji parsial (uji t). 


\section{HASIL DAN PEMBAHASAN}

Gambaran umum mengenai ketenagakerjaan sektor industri besar sedang dan variabel diduga memengaruhinya di Provinsi Jawa Timur tahun 2019.

\section{TENAGA KERJA}

Pada tahun 2019, jumlah tenaga kerja pada sektor industri besar sedang di Provinsi Jawa Timur secara keselurahan sebanyak 1,087 juta jiwa. Jika ditinjau dari jumlah tenaga kerja sektor industri besar sedang menurut kabupaten/kota di Provinsi Jawa Timur, dapat dilihat perbedaan yang cukup besar antar kabupaten/kotanya. Hanya empat kabupaten/kota yang memiliki jumlah tenaga kerja pada sektor industri besar sedang diatas 100 ribu jiwa, yaitu Kabupaten Sidoarjo sebanyak 196,4 ribu jiwa, Kabupaten Pasuruan sebanyak 162,8 ribu jiwa, Kota Surabaya sebanyak 130,2 ribu jiwa, dan Kabupaten Gresik sebanyak 123,6 ribu jiwa. Hal ini cukup timpang jika dibandingkan dengan mayoritas kabupaten/kota lain dengan jumlah tenaga kerja sektor industri besar sedangnya yang berada di bawah 50 ribu jiwa. Bahkan untuk Kabupaten Sampang dengan jumlah tenaga kerja sektor industri besar sedang terendah di Provinsi Jawa Timur hanya mampu menyerap sebanyak 760 jiwa. Hal ini menunjukkan masih belum meratanya sebaran tenaga kerja di sektor industri besar sedang dan terjadi pemusatan terhadap beberapa kabupaten/kota yang diprioritaskan untuk menjadi wilayah penggerak industri di Provinsi Jawa Timur.

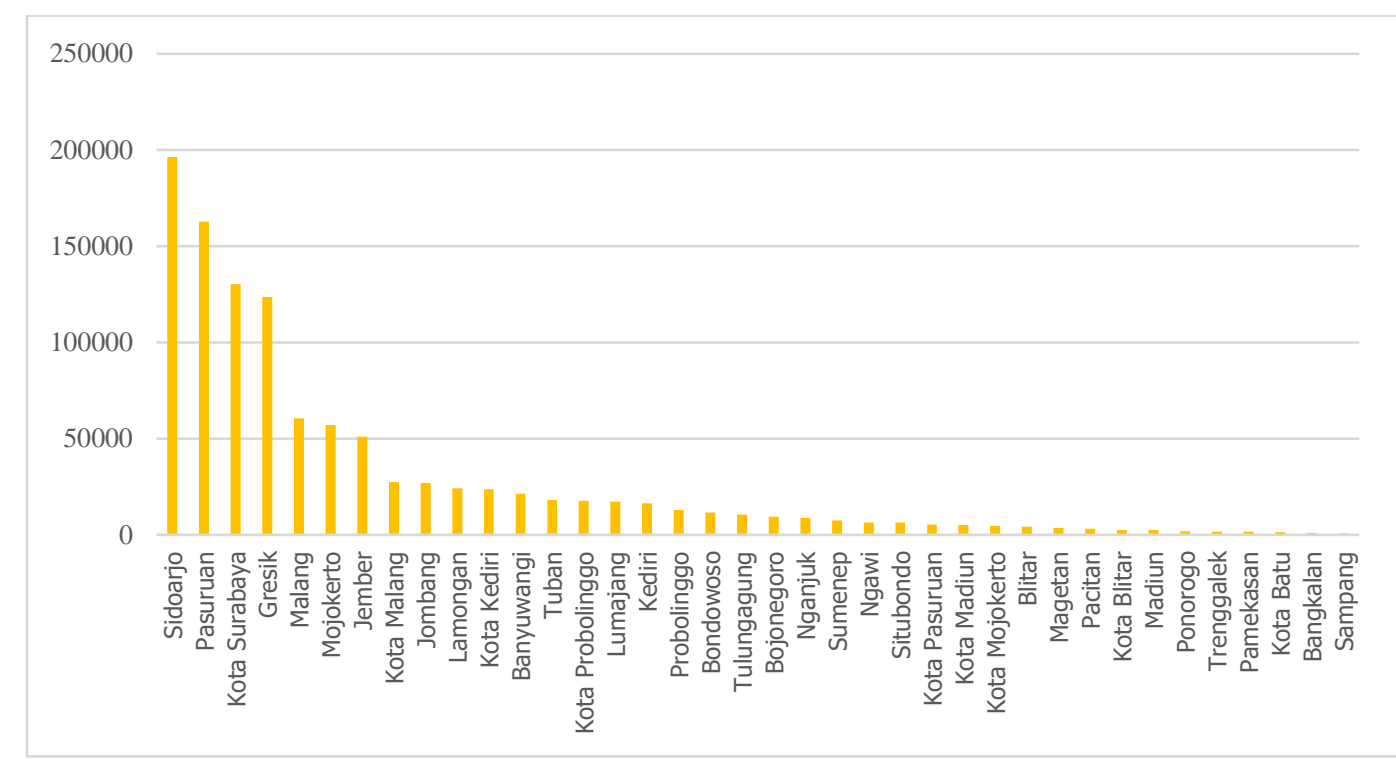

Sumber: Badan Pusat Statistik (diolah)

Gambar 1. Jumlah tenaga kerja industri besar sedang Provinsi Jawa Timur menurut kabupaten/kota tahun 2019.

Sebesar 21,39 persen atau sebanyak 232,7 ribu tenaga kerja sektor industri besar sedang bekerja pada subsektor industri makanan, menjadikan subsektor ini sebagai subsketor dengan tingkat penyerapan tenaga kerja terbesar pada sektor industri besar sedang. Sedangkan subsektor dengan tingkat penyerapan tenaga kerja terendah pada sektor industri besar sedang adalah subsektor produksi batu bara dan pengilangan minyak sebesar 0,26 persen atau sebanyak 282,5 ribu jiwa. 


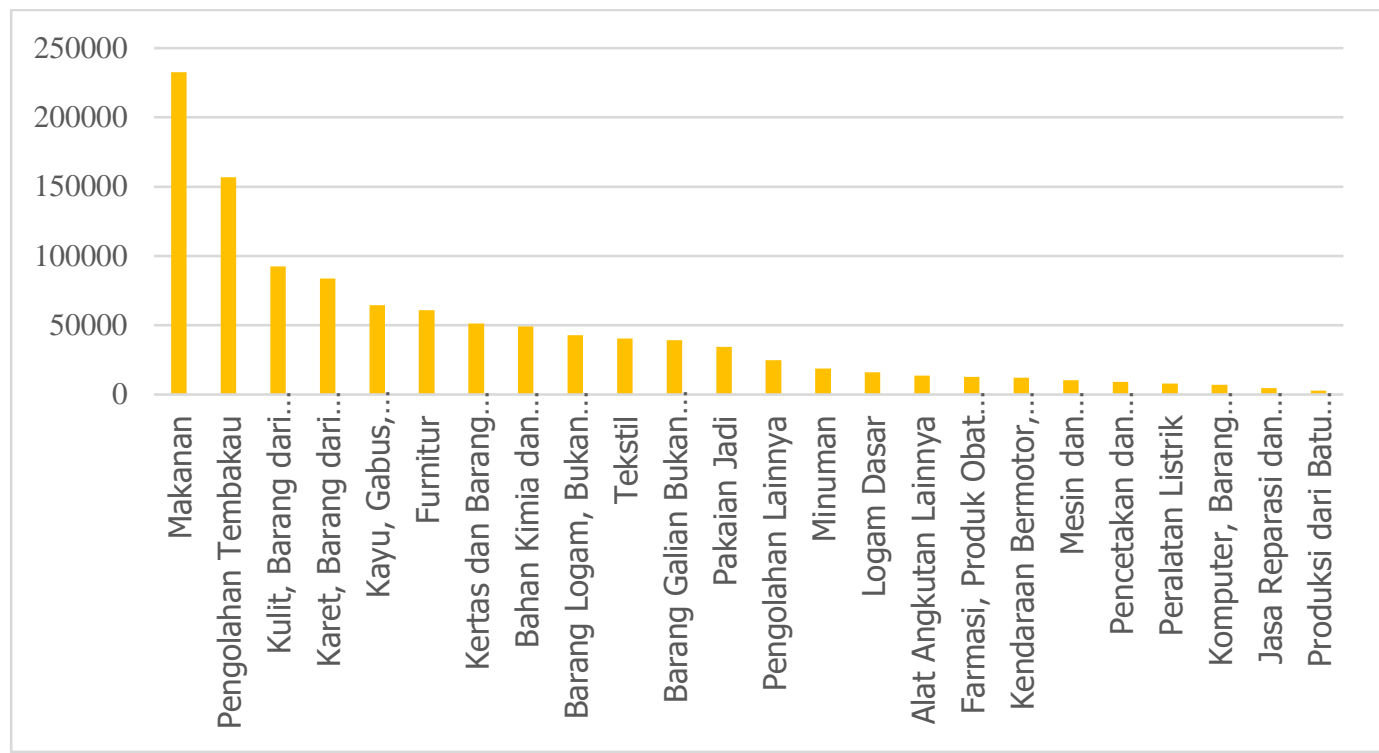

Sumber : Badan Pusat Statistik (diolah)

Gambar 2. Jumlah tenaga kerja industri besar sedang Provinsi Jawa Timur menurut klasifikasi industri tahun 2019.

\section{JUMLAH PERUSAHAAN}

Pada tahun 2019, jumlah perusahaan industri besar sedang di Provinsi Jawa Timur secara keseluruhan mencapai 6756 unit. Berdasarkan Gambar 3, industri besar sedang dengan jumlah perusahaan terbanyak adalah subsektor makanan sebanyak 1770 unit. Hal ini berbanding lurus dengan jumlah tenaga kerja yang diserap terbanyak berasal dari subsektor makanan. Sedangkan industri besar sedang dengan jumlah perusahaan paling sedikit adalah produksi dari batu bara dan pengilangan minyak sebanyak 29 unit. Hal ini juga berbanding lurus dengan jumlah tenaga kerja yang diserap paling sedikit berasal dari sektor produksi bata bara dan pengilangan minyak, ini bisa disebabkan kebanyakan perusahaan industri yang melakukan kegiatan pengolahan seperti ini lebih terfokus pada sistem padat modal dimana lebih mengutamakan penggunaan mesin dan alat-alat canggih dibandingkan tenaga manusia (padat karya). Namun hal ini tidak terjadi pada semua subsektor, seperti pada subsektor karet, barang dari karet dan plastik yang seharusnya dapat berada di posisi kedua dalam penyerapan tenaga kerja setelah subsektor makanan harus berada di posisi keempat setelah pengolahan tembakau dan kulit dan barang dari kulit.

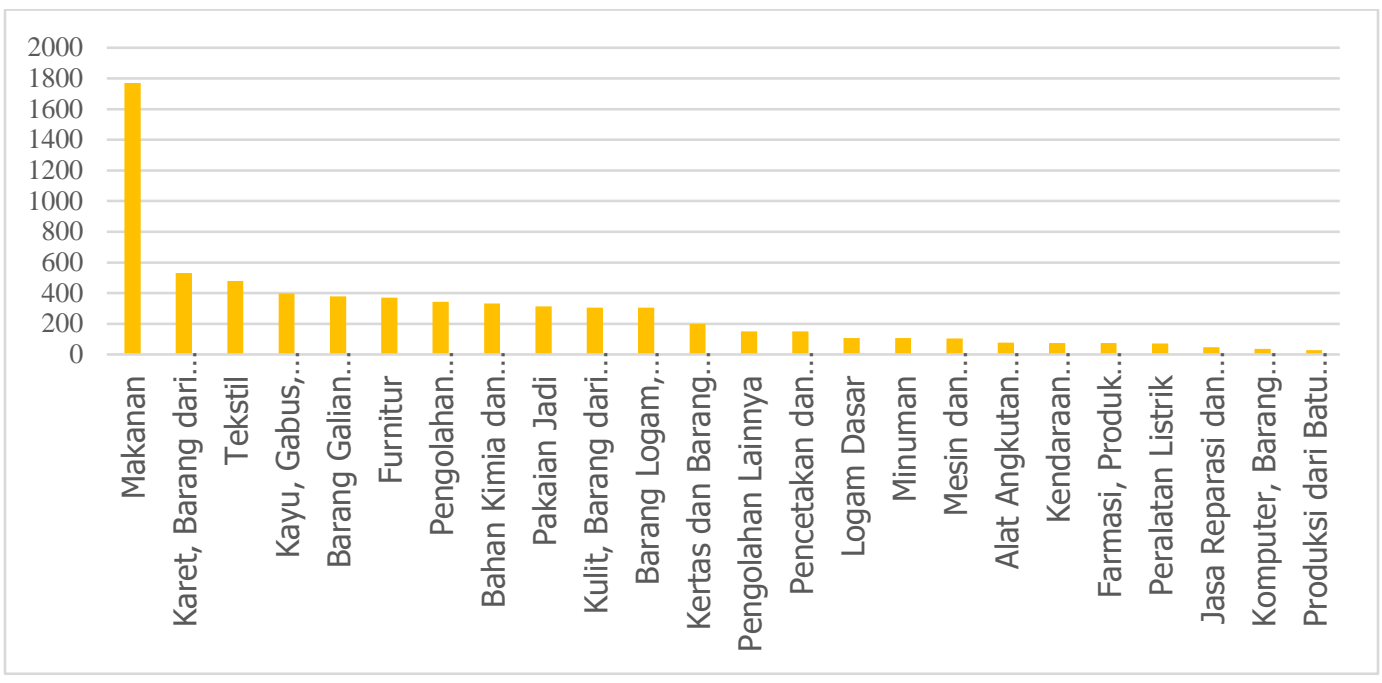

Sumber : Badan Pusat Statistik (diolah)

Gambar 3. Jumlah perusahaan industri besar sedang Provinsi Jawa Timur menurut klasifikasi industri tahun 2019.

Berdasarkan Gambar 4, jumlah perusahaan industri besar sedang menurut kabupaten/kota di Provinsi Jawa Timur juga menunjukkan adanya ketimpangan sebaran yang tidak merata. Misi untuk melakukan 
pemerataan dan penyebaran industri tercantum dalam Nawa Cita Presiden Republik Indonesia Agenda Prioritas ke- 6 butir ke-4 yaitu meningkatkan produktivitas rakyat dan daya saing di pasar internasional sehingga bangsa Indonesia dapat bersama-sama dengan negara Asia lainnya melalui sekurang-kurangnya sepuluh kawasan industri baru. Empat kabupaten/kota dengan jumlah perusahaan terbanyak yaitu Kabupaten Sidoarjo, Kabupaten Pasuruan, Kota Surabaya, dan Kabupaten Gresik. Hal ini berbanding lurus dengan jumlah tenaga kerja industri besar sedang yang diserap pada empat wilayah ini seperti yang dijelaskan pada Gambar 1. Hal ini didukung dengan adanya kawasan industri yang terletak pada wilayahwilayah tersebut. Saat ini kawasan industri Provinsi Jawa Timur berada di Kota Surabaya, Kabupaten Pasuruan, Kabupaten Sidoarjo, Kabupaten Mojokerto, Kabupaten Gresik, dan Kabupaten Tuban. Untuk saat ini pemerintah Provinsi Jawa Timur sedang mengembangkan kawasan industri di wilayah lain sehingga terjadi pemerataan industri, yaitu di Kabupaten Jombang, Kabupaten Lamongan, Kabupaten Banyuwangi, Kabupaten Bangkalan, dan Kabupaten Nganjuk. Sedangkan Kota Blitar berada di urutan terakhir dengan jumlah perusahaan sebanyak 10 unit, tidak sejalan dengan jumlah tenaga kerja industri besar sedang yang diserap.

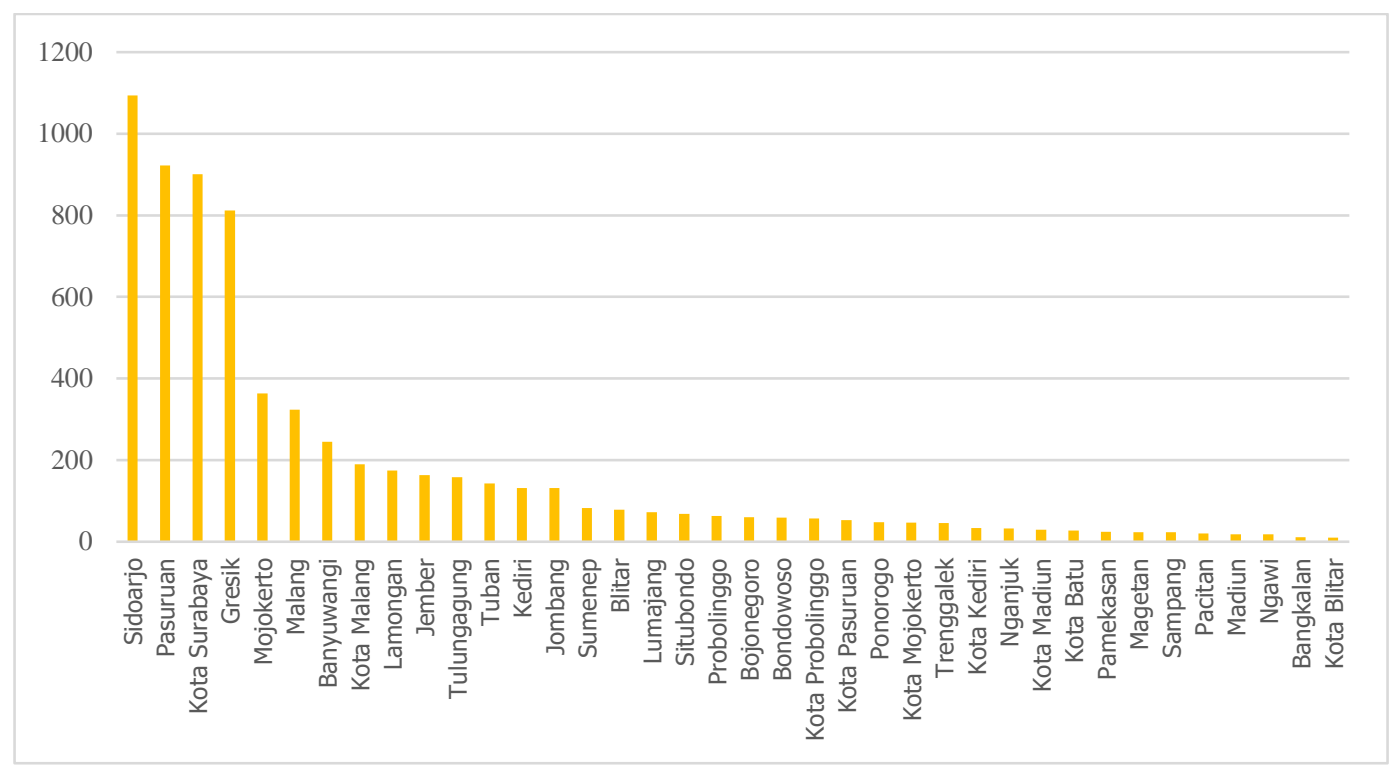

Sumber : Badan Pusat Statistik (diolah)

Gambar 4. Jumlah perusahaan industri besar sedang Provinsi Jawa Timur menurut kabupaten/kota tahun 2019.

\section{PDRB}

Pada tahun 2019, PDRB Provinsi Jawa Timur mencapai 2.352,42 triliun rupiah, sebesar 30,23 persennya atau sekitar 498,8 triliun rupiah merupakan kontribusi dari sektor industri pengolahan. Nilai ini menempatkan sektor industri pengolahan sebagai kontributor terbesar dalam pembentukan PDRB Provinsi Jawa Timur.

Setiap kabupaten/kota di Provinsi Jawa Timur turut berperan dalam kontribusi pembentukan PDRB Provinsi Jawa Timur melalui sektor industri pengolahan, sebagaimana ditunjukkan pada Gambar 5. Kota Kediri merupakan daerah dengan kontribusi PDRB melalui sektor industri pengolahan terbesar yaitu sebesar 114,23 triliun rupiah. Sementara itu, Kabupaten Bangkalan dengan kontribusi PDRB melalui sektor industri pengolahan terkecil yaitu sebesar 439,3 miliar rupiah. Perbedaan ini dapat disebabkan oleh adanya perbedaan dalam faktor-faktor pembentukan PDRB masing-masing daerah seperti nilai investasi, kegunaan teknologi, nilai ekspor, dan indikator relevan lainnya. 


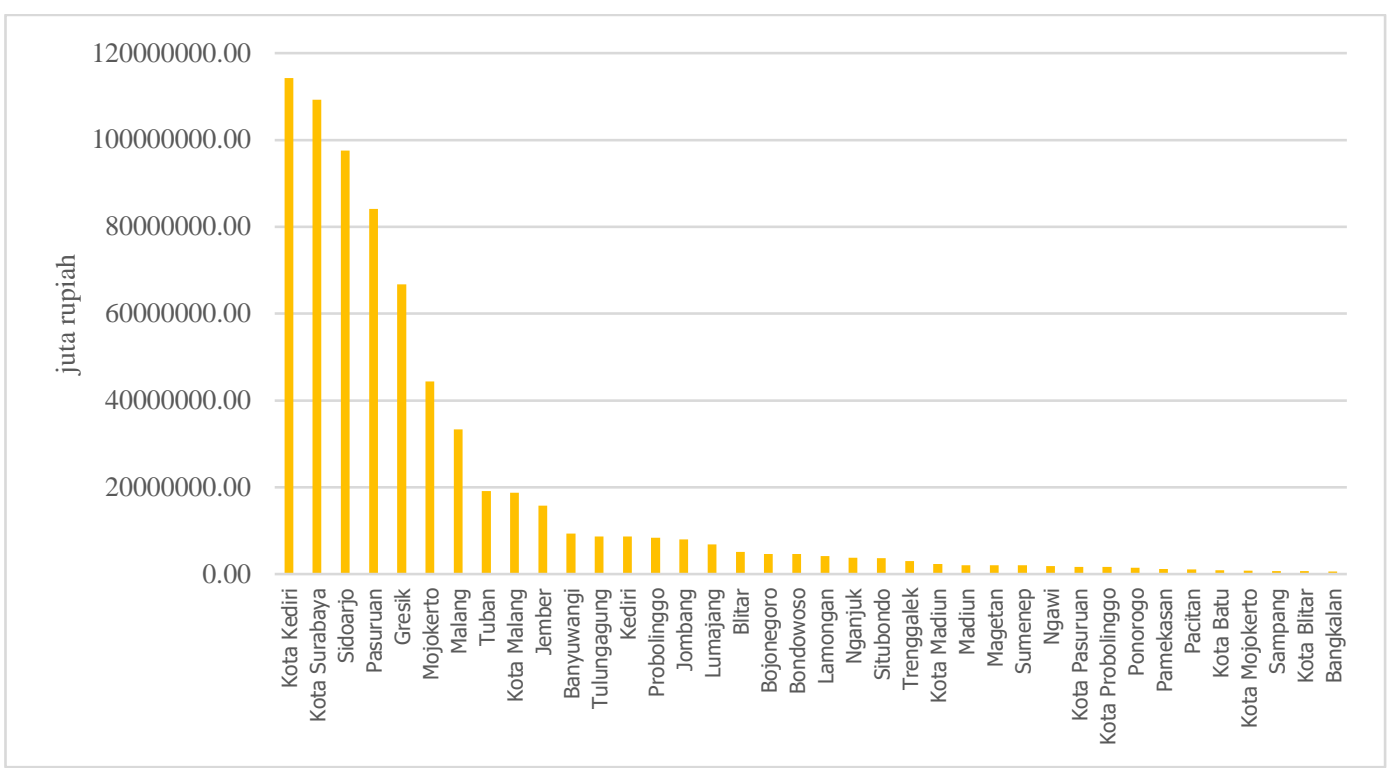

Sumber : Badan Pusat Statistik (diolah)

Gambar 5. PDRB ADHB sektor industri Provinsi Jawa Timur menurut kabupaten/kota tahun 2019.

\section{UMK}

Dengan meningkatnya jenis kebutuhan dalam pemenuhan, penyesuaian, dan penambahan jenis kualitas komponen hidup layak menjadi salah satu faktor kenaikan upah minimum yang terjadi setiap tahunnya di Provinsi Jawa Timur. Upah Minimum ditetapkan oleh pemerintah dengan didasarkan pada KLH (Kebutuhan Hidup Layak) seperti yang diatur dalam Undang-Undang Nomor 13 Tahun 2003 Tentang Ketenagakerjaan. Gubernur dapat menetapkan UMK dengan adanya pertimbangan dari walikota maupun bupati, serta dengan kesepakatan organisasi perusahaan dan serikat pekerja pada sektor yang bersangkutan.

Berdasarkan Gambar 6 dapat dilihat bahwa upah minimum di Provinsi Jawa Timur pada tahun 2019 tidak menunjukkan perbedaan yang terlalu signifikan antar wilayahnya. Bahkan untuk beberapa wilayah yang berdekatan memiliki nilai upah minimum yang sama. Kota Surabaya menjadi wilayah yang memiliki upah minimum tertinggi di Provinsi Jawa Timur yaitu sebesar 3,87 juta rupiah disusul oleh Kabupaten Gresik, Kabupaten Sidoarjo, dan Kabupaten Pasuruan sebesar 3,86 juta rupiah. Sedangkan wilayah-wilayah dengan upah terendah adalah Kabupaten Pacitan, Kabupaten Ponorogo, Kabupaten Trenggalekm Kabupaten Situbondo, Kabupaten Madiun, Kabupaten Magetan, Kabupaten Ngawi, Kabupaten Sampang, dan Kabupaten Pamekasan dengan nilai yang sama sebesar 1,76 juta rupiah.

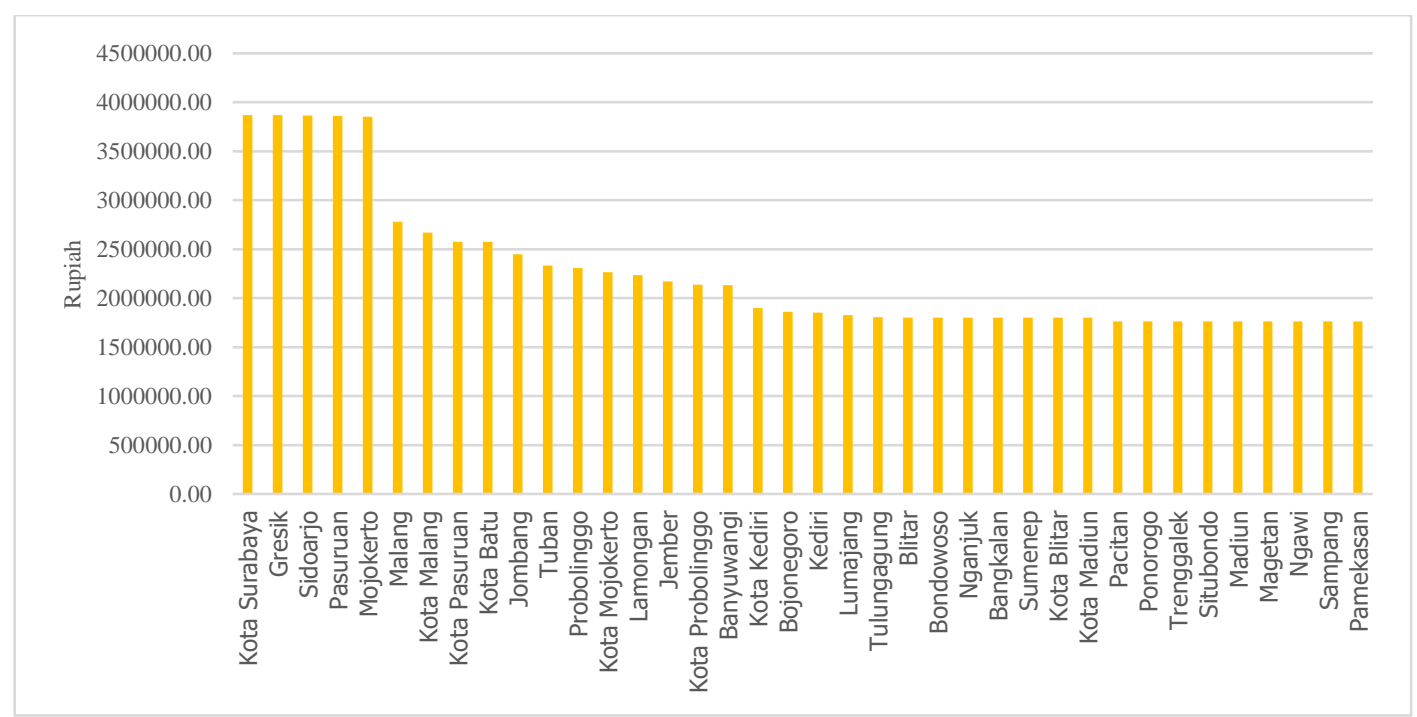

Sumber : Badan Pusat Statistik (diolah)

Gambar 6. UMK Provinsi Jawa Timur menurut kabupaten/kota tahun 2019. 


\section{ANALISIS VARIABEL-VARIABEL YANG MEMENGARUHI PERMINTAAN TENAGA KERJA INDUSTRI BESAR SEDANG PROVINSI JAWA TIMUR TAHUN 2019}

Ketika dilakukan analisis RLB didapatkan hasil analisis yang melanggar asumsi heteroskedastisitas dan normalitas, untuk mengatasi masalah tersebut, data awal akan ditransformasi menjadi bentuk logaritma natural (In). Sehingga hasil estimasi model dapat ditulis dalam persamaan sebagai berikut :

$$
\widehat{L n Y}=-7.095+0.4631 \ln X 1+0.4676 \ln X 2+0.4854 \ln X 3
$$

Untuk mengetahui apakah model yang dihasilkan sudah baik, diperlukan pengujian asumsi klasik yaitu heteroskedastisitas, normalitas, multikolinieritas, dan autokorelasi. Adapun hasil pengujian asumsi klasik, sebagai berikut:

Uji heteroskedastisitas bertujuan untuk mengetahui apakah terdapat perbedaan varians dari residual untuk semua nilai amatan pada model regresi. Pada penelitian ini digunakan uji Glejser dengan cara meregresikan nilai absolut dari residual dengan semua variabel bebas. Diperoleh $p$-value sebesar 0,071 dimana nilai ini lebih besar dari 0,05 . Hal ini menunjukan bahwa model yang terbentuk terbebas dari gejala heteroskedastis.

Uji normalitas digunakan untuk melihat apakah residual pada data yang diteliti telah berdistribusi normal atau tidak. Model regresi yang baik ditunjukkan dengan residual yang berdistribusi normal. Uji asumsi normalitas dalam penelitian ini dilakukan dengan menggunakan uji Jarque-Bera. Diperoleh $p$-value sebesar 0,902. Karena $p$-value $>0,05$, maka dapat disimpulkan bahwa residual telah memenuhi asumsi kenormalan.

Uji multikolinearitas bertujuan untuk menguji apakah suatu model regresi memiliki korelasi antar variabel bebas. Pengujian multikolinearitas dilihat dari besaran VIF (Variance Inflation Factor). Nilai cut off yang umum dipakai untuk menunjukan tidak terjadi multikolinearitas dalam model regresi adalah nilai VIF < 10. Diperoleh nilai VIF pada setiap variabel independen bernilai $<10$. Hal ini menunjukan bahwa setiap variabel terbebas dari multikolinearitas.

Uji autokorelasi dalam penelitian ini bertujuan untuk menguji dan mengetahui apakah terdapat hubungan antar wilayah. Pengujian autokorelasi menggunakan uji Durbin-Watson, dimana uji ini akan menghasilkan nilai Durbin Watson (dW) yang nantinya akan dibandingkan dengan dua nilai Durbin Watson pada tabel yaitu Durbin Lower (dL) dan Durbin Upper (dU). Apabila nilai dW > dU, maka dapat dikatakan tidak terjadi autokorelasi antar data atau wilayah. Adapun hasil yang diperoleh yaitu nilai dW sebesar 1,478, nilai ini berada di antara nilai dU dan dL $(1,3177<1,478<1,6563)$ sehingga kondisi ini tidak dapat disimpulkan apakah terdapat autokorelasi atau tidak. Kemudian dilanjutkan dengan menggunakan uji Run untuk mengetahui dan mendapatkan hasil yang lebih akurat apakah terjadi autokorelasi atau tidak. Didapatkan hasil $p$-value sebesar 0,250, dimana nilai ini lebih besar dari 0,05 sehingga keputusan yang diambil adalah gagal tolak $\mathrm{H}_{0}$ dan dapat disimpulkan tidak terjadi autokorelasi.

Uji $\mathrm{F}$ dalam penelitian ini merupakan uji yang dilakukan untuk melihat apakah terdapat pengaruh variabel independen yaitu terhadap variabel dependen yaitu jumlah tenaga kerja secara simultan atau bersama-sama. Pengujian ini dilakukan dengan menggunakan $p$-value yang dibandingkan dengan nilai $a=$ 0,05 , diperoleh $p$-value sebesar 0,000 . Nilai ini kurang dari 0,05 , sehingga keputusannya adalah tolak $\mathrm{H}_{0}$ dengan kesimpulan bahwa dari ketiga variabel independen minimal terdapat 1 variabel yang berpengaruh signifikan terhadap jumlah tenaga kerja sektor industri besar sedang di Provinsi Jawa Timur tahun 2019 pada tingkat signifikansi sebesar 5 persen.

Koefisien determinasi dalam analisis regresi linear berganda digunakan untuk menunjukkan seberapa besar varians dari variabel dependen yang dapat dijelaskan oleh variabel independen. Nilai koefisien determinasi dalam penelitian ini menggunakan adjusted $R^{2}$. Diperoleh nilai adjusted $R^{2}$ sebesar 0,86 . Hal ini menunjukkan bahwa variasi jumlah tenaga kerja sektor industri besar sedang Provinsi Jawa Timur yang dapat dijelaskan oleh variabel jumlah perusahaan, PDRB, dan UMK sebesar 86 persen, sedangkan sisanya sebesar 14 persen dijelaskan oleh variabel lain diluar variabel yang digunakan dalam model.

Uji t dalam penelitian ini bertujuan untuk melihat besarnya pengaruh masing-masing variabel terhadap variabel dependen secara parsial. Pengujian ini dilakukan dengan menggunakan $p$-value yang dibandingkan dengan nilai $a=0,05$. Hasil pengolahan menunjukkan bahwa variabel In jumlah perusahaan industri besar sedang dan In PDRB sektor industri memiliki $p$-value $<0,05$ artinya $\mathrm{H}_{0}$ ditolak, sehingga dapat disimpulkan 
bahwa variabel yang berpengaruh signifikan terhadap In jumlah tenaga kerja sektor industri besar sedang Provinsi Jawa Timur tahun 2019 pada tingkat signifikansi 5 persen. Sedangkan untuk variabel In UMK memiliki $p$-value $>0,05$ artinya $\mathrm{H}_{0}$ gagal tolak, sehingga dapat disimpulkan bahwa variabel In UMK tidak berpengaruh signifikan terhadap $\mathrm{n}$ jumlah tenaga kerja sektor industri besar sedang Provinsi Jawa Timur tahun 2019 pada tingkat signifikansi 5 persen.

Berdasarkan hasil penelitian, didapatkan hasil bahwa koefisien variabel In jumlah perusahaan industri besar sedang sebesar 0,463 yang artinya setiap adanya peningkatan jumlah perusahaan sebesar satu persen, maka akan meningkatkan jumlah tenaga kerja sektor industri besar sedang 0,463 persen dengan asumsi variabel lain bernilai konstan. Hasil penelitian ini menunjukkan bahwa jumlah perusahaan berpengaruh positif dan signifikan terhadap jumlah tenaga kerja pada tingkat signifikansi sebesar 5 persen. Hal ini sejalan dengan penelitian yang dilakukan oleh Pradikta (2010) bahwa jumlah perusahaan memiliki hubungan positif signifikan terhadap jumlah tenaga kerja. Jika jumlah perusahaan di suatu daerah meningkat maka akan meningkatkan penyerapan jumlah tenaga kerja. Penelitian ini menunjukkan bahwa jumlah perusahaan berpengaruh signifikan terhadap jumlah tenaga kerja. Berdasarkan data BPS, jumlah perusahaan industri di Provinsi Jawa Timur dari tahun ke tahun mengalami peningkatan, hal yang sama juga ditunjukkan pada jumlah tenaga kerja sektor industri terutama industri besar sedang. Hal ini menunjukkan bahwa dengan meningkatnya jumlah perusahaan artinya meningkatkan juga ketersediaan lapangan kerja baru yang mampu menyerap tenaga kerja baru yang dibutuhkan oleh perusahaan tersebut.

Berdasarkan hasil penelitian, didapatkan hasil bahwa koefisien variabel In PDRB sebesar 0,467 yang artinya setiap peningkatan nilai PDRB pada sektor industri sebesar satu persen, maka akan meningkatkan jumlah tenaga kerja pada sektor industri besar sedang sebesar 0,467 persen dengan asumsi variabel lain bernilai konstan. Hasil penelitian ini menunjukkan bahwa jumlah perusahaan berpengaruh positif dan signifikan terhadap jumlah tenaga kerja pada tingkat signifikansi sebesar 5 persen. Penyerapan tenaga kerja yang tinggi terjadi pada wilayah dengan aktifitas ekonomi yang tinggi, salah satu tolok ukur kegiatan perekonomian suatu wilayah adalah PDRB. Peningkatan nilai PDRB berarti terjadi peningkatan kegiatan ekonomi yang dapat meningkatkan jumlah tenaga kerja di sektor produktif dan menurunkan jumlah pengangguran, begitu juga sebaliknya (Lavianty, 2016). Sesuai dengan pernyataan Mankiw (2006) yang menjelaskan bahwa hukum Okun (Okun's Law) merupakan hubungan negatif antara pengangguran dan GDP yang mengacu pada penurunan dalam pengangguran sebesar satu persen akan meningkatkan GDP riil mendekati 2 persen. Dengan kata lain, PDRB yang pada akhirnya mempengaruhi GDP berpengaruh positif terhadap penyerapan tenaga kerja. Peningkatan jumlah PDRB akan berpengaruh pada peningkatan penyerapan tenaga kerja, begitu juga sebaliknya penurunan jumlah PDRB akan berpengaruh pada penurunan penyerapan tenaga kerja.

Berdasarkan hasil penelitian, didapatkan hasil bahwa koefisien variabel In UMK sebesar 0,485. Hasil penelitian pada tabel 1 menunjukkan variabel ini tidak signifikan terhadap penyerapan tenaga kerja sektor industri besar sedang di Provinsi Jawa Timur tahun 2019 sehingga tidak akan diinterpretasikan nilai dari koefisien variabel tersebut. Hasil penelitian ini tidak sesuai dengan hipotesis yang diduga karena upah minimum yang terus meningkat di kabupaten/kota di Provinsi Jawa Timur dapat menyebabkan pengeluaran perusahaan yang turut meningkat, sehingga terpaksa membuat perusahaan menerapkan sistem PHK (Pemutusan Hubungan Kerja) agar tidak memberatkan perusahaan. Hasil penelitian ini tidak sesuai dengan hipotesis yang diduga karena upah minimum yang terus meningkat di kabupaten/kota di Provinsi Jawa Timur dapat menyebabkan pengeluaran perusahaan yang turut meningkat, sehingga terpaksa membuat perusahaan menerapkan sistem PHK (Pemutusan Hubungan Kerja) agar tidak memberatkan perusahaan. Hal ini akan menyebabkan perusahaan mulai beralih dari padat karya menjadi padat modal. Penetapan upah minimum yang tinggi dapat menyebabkan pengurangan tenaga kerja pada sektor formal namun dapat meningkatkan tenaga kerja di sektor informal. Peningkatan tenaga kerja pada sektor informal yang semakin meningkat dapat menyebabkan kebijakan upah minimum yang telah ditetapkan oleh pemerintah daerah tidak dapat dilaksanakan dengan seharusnya, karena secara umum upah pekerja di sektor informal berada di bawah upah minimum yang ditetapkan pemerintah. Sehingga, hal ini yang menyebabkan upah minimum kabupaten/kota di Provinsi Jawa Timur tidak signifikan memengaruhi penyerapan tenaga kerja di sektor industri besar sedang.

\section{KESIMPULAN}

Berdasarkan analisis yang telah dilakukan diperoleh kesimpulan yaitu mayoritas tenaga kerja sektor industri besar sedang di Provinsi Jawa Timur pada tahun 2019 berada pada Kabupaten Sidoarjo, Kabupaten Pasuruan, dan Kota Surabaya serta umumnya bekerja pada subsketor pengolahan makanan. Jumlah perusahaan industri besar sedang terbanyak berada di Kabupaten Sidoarjo dan yang terendah berada di Kota Blitar. Daerah dengan nilai PDRB sektor industri tertinggi adalah Kota Surabaya dan yang terendah adalah Kabupaten Bangkalan. Kemudian Kota Surabaya merupakan daerah dengan UMK tertinggi, serta 1182 
terdapat beberapa daerah dengan nilai UMK yang sama dan menjadikan mereka sebagai daerah-daerah dengan nilai UMK terendah yaitu Kabupaten Pacitan, Kabupaten Ponorogo, Kabupaten Trenggalek, Kabupaten Situbondo, Kabupaten Madiun, Kabupaten Magetan, Kabupaten Ngawi, Kabupaten Sampang, dan Kabupaten Pamekasan. Seluruh variabel independen yang digunakan pada penelitian ini yaitu jumlah perusahaan, PDRB, serta UMK secara simultan atau bersama-sama berpengaruh terhadap penyerapan tenaga kerja sektor industri besar sedang di Provinsi Jawa Timur tahun 2019. Secara parsial, jumlah perusahaan dan PDRB menunjukkan hubungan yang positif dan signifikan sedangkan variabel UMK menunjukkan hubungan yang positif dan tidak signifikan.

Terdapat beberapa saran yang dapat disampaikan melalui penelitian ini yaitu Perlu adanya usaha pemerataan unit usaha kegiatan industri besar sedang di seluruh kabupaten/kota di Provinsi Jawa Timur sehingga tidak terpusat atau terkonsentrasi hanya pada beberapa wilayah-wilayah tertentu saja. Pemerintah dapat meningkatkan penyerapan tenaga kerja sektor industri besar sedang di Provinsi Jawa Timur dengan mengembangkan industri mikro kecil yang sudah ada agar dapat menjadi industri besar dan sedang. Pemerintah dapat melakukan evaluasi terhadap UMK yang ditetapkan, karena memberatkan perusahaan dalam memenuhi biaya input produksinya. Diharapkan juga untuk penelitian berikutnya dapat menggunakan rentang waktu yang lebih panjang.

\section{DAFTAR PUSTAKA}

Badan Pusat Statistik. (2017). Statistik Industri Manufaktur 2017. Jakarta: Badan Pusat Statistik Republik Indonesia.

Badan Pusat Statistik Provinsi Jawa Timur. (2019). PDRB Provinsi Jawa Timur Menurut Lapangan Usaha Tahun 2014-2018. Surabaya: Badan Pusat Statistik Provinsi Jawa Timur.

Badan Pusat Statistik Provinsi Jawa Timur. (2020). Provinsi Jawa Timur Dalam Angka 2020. Surabaya: Badan Pusat Statistik Provinsi Jawa Timur.

Dinas Tenaga Kerja dan Transmigrasi Provinsi Jawa Timur. (2018). Keputusan Gubernur Jawa Timur Nomor 188/665/KPTS/013/2018 Tentang Upah Minimum Kabupaten/Kota di Jawa Timur Tahun 2019. Surabaya: Dinas Tenaga Kerja dan Transmigrasi Provinsi Jawa Timur.

Lavianty, Melia Elmy. (2016). Pengaruh PDRB, Investasi, Upah dan Inflasi Terhadap Penyerapan Tenaga Kerja di Pulau Jawa Tahun 2008-2013 [Skripsi]. Bandung: Universitas Pasundan.

Mankiw, Gregory N. (2006). Makro Ekonomi (Edisi Ketiga). Jakarta: Chriswan Sungkono [penerjemah] Salemba Empat.

Pradikta, Ganda. (2010). Pengaruh Jumlah Perusahaan, Nilai Tambah, dan Upah Terhadap Penyerapan Tenaga Kerja Pada Sektor Industri Tekstil Padat Karya di Jawa Timur [Skripsi]. Surabaya: Universitas Airlangga.

Simanjuntak, Payaman J. (2001). Pengantar Ekonomi Sumber Daya Manusia. Jakarta: FE UI.

Sumarsono, S. (2009). Ekonomi Sumber Daya Manusia Teori dan Kebijakan Publik. Yogyakarta: Graha Ilmu. Tambunan, Tulus. (2001). Perekonomian Indonesia: Teori dan Temuan Empiris. Jakarta: Ghalia Indonesia.

Undang-Undang No. 25 Tahun 1997 tentang Ketenagakerjaan.

Undang-Undang No. 13 Tahun 2003 tentang Ketenagakerjaan. 